DOI https://doi.org/10.30525/978-9934-588-37-2.1.12

\title{
МОДЕЛЬ СИСТЕМНОГО ОПИСУ ІМІДЖУ ОСОБИСТОСТІ
}

\section{Демчук Т. П.}

\section{ВСТУП}

Психологію іміджу можна означити як розділ психологічної науки, наукову теорію, предметом якої є імідж як соціально-психологічний феномен, а також закономірності його виникнення і функціонування. Імідж особистості розглядається як поєднання внутрішніх і зовнішніх чинників, що задають його складові.

Серед зарубіжних спеціалістів, що займаються дослідженнями i практичними розробками в галузі формування іміджу та іміджу особистості, слід назвати таких фахівців, як П. Берд, З. Блек, Ф. Буарі, П. Вейл, Т. Сван, М. Спіллейн, Р. Хофф, П. Чисхольм, Б. Швальбе та ін.

Серед досліджень на території пострадянського простору присутні праці про роль і значення іміджу в різних сферах соціального життя (Е.Н. Богданов, С.Д. Максименко, В.Й. Бочелюк, А.В. Гармонова, В.Г. Зазикін, З.М. Зотова, Е.В. Егорова-Гантман, А.Ю. Панасюк, Ю.В. Синягін та ін.); праці, які направлені на вивчення принципів, механізмів і технологій формування іміджу політика (Е.В. Аверін, I.Н. Гомеров, О.І. Гордєєва, Н.А. Гульбінський, П.С. Гуревич, І.Г. Дубів, О.В. Іванникова, А.Ю. Панасюк, Г.Г. Почепцов, Н.А. Сорокіна, О.Н. Феофанов, Р.Ф. Фурс, Е.Б. Шестопал та ін.), бізнесмена (Е.А. Блажнов, В.А. Іванченко, Р.Л. Кричевський, Ф.А. Кузін, В.М. Шепель та ін.), державного службовця (В.В. Дашевський, Л.В. Льдова, Н.А. Орлова та ін.), педагога (С.Д. Максименко, В.Й. Бочелюк, О.О. Деркач, Н.В. Кузьміна, А.К. Маркова, А.А. Реан, I.А. Зязюн, А.О. Кононенко, О.О. Грейліх та ін.).

Разом з матеріалами досліджень, безпосередньо присвячених іміджу, є обширний масив теоретичних і емпіричних даних, прямо або опосередковано пов'язаних з проблематикою іміджу.

У пострадянській психологічній традиції безпосереднє відношення до дослідження явищ іміджу мають такі напрями досліджень, як вивчення сприйняття, зокрема побудова образу, аналіз індивідуальної і колективної діяльності, дослідження спілкування i соціального пізнання (Б.Г. Ананьєв, В.Л. Барабанщиков, А.А. Бодальов, А.В. Запорожець, В.П. Зінченко, А.Н. Леонтьєв, А.Д. Логвиненко, С.Д. Смирнов, Е.Н. Соколов і ін.). 
Не менш важливе значення для досліджень іміджу має розробка проблематики спілкування як суб'єкт-суб'єктної взаємодії (Б.Г. Ананьєв, К.А. Абульханова-Славська, А.Г. Асмолов, О.О. Бодальов, А.А. Леонтьєв, А.В. Брушлінський, Б.Ф. Ломов, С.Л. Рубінштейн, В.В. Рубцов і ін.), що одержала конкретизацію в дослідженні проблем соціального сприйняття і соціального пізнання (В.С. Агєєв, Г.М. Андрєєва, Н.Н. Богомолова, А.І. Донцов, М.Ю. Кондратьєв, В.А. Лабунська, Т. Г. Стефаненко, В.Ф. Петренко, А.Г. Шмельов і ін.).

Дослідження іміджу відбувалося i через осмислення самопрезентації і стратегій самоподачі, аналізу міжособистісного зворотного зв'язку, розроблення ефективних психотехнологій (О.С. Анісімов, Р. Баумейстер, Дж. Готлі, Е. Гоффман, Е. Джонс, Є.Л. Доценко, В.Г. Зазикін, З. Карвер, А.В. Кириченко, А.Ю. Панасюк, Л.А. Петровська, О.В. Соловйова, А.О. Кононенко і ін.).

\section{1. Короткий опис сучасних наукових поглядів на сутність іміджа особистості}

За загальним визначенням імідж - це сукупність символічних властивостей, що приписуються об'єкту і свідчать про його високий соціальний престиж, привабливість, адекватність, життєвість, пошану тощо ${ }^{1}$.

Імідж $є$ феноменом буденної свідомості, яка важається іманентною формою відображення дійсності, своєрідною організацією знань i характеризується конкретністю, нерозчленованістю, переплетенням істинних i неправдивих уявлень, встановленням найчастіше випадкових зв'язків між знову виявленими і вже відомими явищами ${ }^{2}$. Діапазон рівнів організації буденної свідомості надзвичайно широкий від найнижчих, «примітивних», що проявляються у вигляді забобонів, до вищих - усвідомлення емпіричних залежностей.

1. Основні властивості буденної свідомості - конкретність та образність. «Конкретність, образність, яскравість фактів призводять до того, що вони стають своєрідним «путівником» зміни буденної свідомості: спираючись на них, класифікуючи їх, суб'єкт аргументує для себе виправданість прийняття тієї або іншої концепції, правомірність тієї або іншої дії» ${ }^{3}$.

2. В.М. Шепель, називаючи буденну свідомість «точкою опори» іміджу, акцентував на тому, що між ними є «своєрідна комунікативна

${ }_{1}^{1}$ Шепель В.М. Имиджелогия. Секреты личного обаяния. Москва, 1994. 384 с. та ін.

Дубинин И.И. Динамика обыденного сознания. Минск : изд-во «Университетское», 1985. 224 с. С. 16.

${ }^{3}$ Там же. С. 18. 
спільність», за допомогою якої й обиватель, у якого активно виступає буденна свідомість, й освічена людина, у якої переважає теоретична свідомість, включаючись в «силове поле» спілкування, «нерідко мимоволі віддають себе ефекту вражень і психічному зараженню»

Відповідно до положень загальної теорії іміджу основними ознаками останнього $є$ :

1) імідж існує незалежно від того предмета, публічним портретом якого він $\epsilon$; це поняття набагато ширше і місткіше, ніж сам предмет, це його «свідома ідеалізація»;

2) імідж є особливим видом ідеалу, який матеріалізується тільки тоді, коли стає публічним, бо він не факт реального світу, а лише уявлення про цей факт; тут увага акцентується на специфічних, тобто тих, які відрізняють конкретний предмет від однорідних 3 ним предметів, особливостях;

3) імідж може базуватися як на «фантомних», тобто бажаних, але відсутніх насправді, так i на реальних якостях відтворюваного предмета; при цьому співвідношення цих якостей має бути адекватним, а перебільшення - не виходити за рамки здорового глузду;

4) імідж має бути образним, апелювати до почуттів, створювати «емоційну реальність», при цьому важливо створити навколо іміджу (стимулу) «коаліцію почуттів», що забезпечує некритичний розгляд;

5) імідж завжди спрощений порівняно $з$ предметом, вигляд якого він відтворює;

6) імідж завжди неоднозначний, залишається як би незавершеним, нечітким, розмитим; він як би знаходиться десь між уявою і почуттями, очікуванням і реальністю; суб'єкт сприйняття сам конкретизує нечіткий зміст іміджу, доповнюючи його власним досвідом, тому імідж є своєрідним відображенням очікувань суб' єкта-реципієнта: при «домальо-

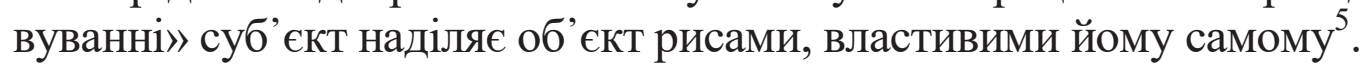

На цей момент не існує однозначного визначення іміджу.

Погляди дослідників, що визначають зміст категорії іміджу, зв'язуються з такими варіантами:

1) феномен індивідуальної, групової або масової свідомості, який функціонує як образ - уявлення, у якому у складному взаємозв'язку поєднуються зовнішні і внутрішні характеристики об'єкта, його соціальні ролі і функції, взаємодія в семантичному полі культури з іншими категоріями свідомості, включеність в менталітет ${ }^{6}$;

2) «прояв внутрішніх відчуттів i власних уявлень про себе 3 урахуванням стереотипів сприйняття навколишніх людей» ${ }^{7}$;

${ }^{4}$ Шепель В.М. Имиджелогия. Секреты личного обаяния. Москва, 1994. 384 с. С. 34

${ }^{5}$ Бурстин Д. Імидж. Санкт-Петербург : Питер, 2000. 216 с. С. 30-31.

${ }^{6}$ Петрова Е.А. Визуальная психосемиотика общения. Москва, 2000. 452 с. С. 27.

${ }^{7}$ Нефедова И. Я и мой имидж. Москва : Яуза : ЭКСМО-Пресс, 1997. 208 с. С. 72. 
3) «соціальний образ, який прагне ідеалу» ${ }^{8}$;

4) «публічне «Я» людини» ${ }^{9}$;

5) специфічний «образ» сприйманого об’єкта, коли ракурс сприйняття навмисне зміщений і акцентуються лише певні сторони об' єкта або явища» ${ }^{10}$;

6) «образ, уявлення, що методом асоціацій наділяє об’єкт додатковими цінностями (соціальними, естетичними, психологічними тощо), не обгрунтованими реальними властивостями самого об' єкта, але такими, що мають соціальну значущість для тих, хто сприймає такий образ»» ${ }^{11}$

7) «відносно стійке уявлення про який-небудь об’ єкт» ${ }^{12}$;

8) «думка», яка склалася про кого-небудь у певної групи людей і яка складає основу «репутації» ${ }^{13}$;

9) «імідж є віддзеркаленням у свідомості людей всієї структури, а точніше сукупності професійно значущих характеристик особи, іiі глибинних рис і прагнень» ${ }^{14}$;

10) «набір певних якостей, які люди асоціюють 3 певною індивідуальністю» ${ }^{15}$;

11) «поняття «імідж» синонімічне до «персоніфікації», але узагальнене, що включає не лише природні властивості людини, а й спеціально напрацьовані, створені, пов'язані як із зовнішнім виглядом, так і з внутрішньою сутністю людини, iї психологічним типом, риси ї мають відповідати запитам часу і суспільства» ${ }^{16}$;

12) ореол, створюваний «засобами масової інформації, соціальною групою або власними зусиллями особистості з метою привернення до себе уваги» ${ }^{17}$.

8 Орлова Е.А. Формирование позитивного имиджа государственного деятеля (Социально-психологический аспект) : дис. ...канд. психол. наук : 19.00.05. Москва, 1997. 217 c. C. 20.

${ }^{9}$ Почепцов Г.Г. Имиджелогия : теория и практика. Киев, 1998. 392 с. С. 16.

10 Андреева Г.М. Социальная психология : учебник для высших учебных заведений. Москва : Аспект Пресс, 2001. 376 с. С. 164

${ }_{11}$ Феофанов О.А. Агрессия лжи. Москва, 1987. 228 с. С. 90.

12 Зверинцев А.Б. Коммуникационный менеджмент. Санкт-Петербург, 1997. 286 c. C. 194.

${ }^{13}$ Панасюк А.Ю. Вам нужен имиджмейкер? Или о том, как создать свой имидж. Москва, 1998. 346 с. С. 10.

14 Пызин В.А. Профессиональный выбор и отбор персонала. Москва, 1997. 244 c. C. $119-120$.

${ }^{15}$ Егорова-Гантман Е. Политическая реклама. Москва, 1999. 327 с. С. 117

${ }^{16}$ Гуревич П. Приключение имиджа. Москва, 1995, 226 с. С. 23

17 Шепель В.М. Имиджелогия. Как нравиться людям. Москва : Народное образование, 2002.576 с. С. 30. 
Вищенаведені і не наведені тут визначення іміджу формують різноманітність дослідницьких позицій при вивченні іміджу.

На сучасному етапі розвитку науки виділяються кілька підходів до вивчення іміджу особистості. Серед них найбільш розробленими є: семіотичний, соціально-психологічний, соціально-перцептивний, акмеологічний, інтерсуб'ектний, комунікативний, суб'єктно-діяльнісний ${ }^{18}$.

Основним постулатом семіотичного підходу є уявлення про те, що імідж - це знакове утворення, «знаковий замінник», «одиниця символічного світу» ${ }^{19}$; «візуальний психосеміотичний знак», «візуальний текст спілкування» ${ }^{20}$; «наочний прояв фрагмента реальності, яке втілює ідею в виразної, символічній формі» ${ }^{21}$, «символічно виражене уявлення про своєрідність і специфіку, унікальність чого-небудь» ${ }^{22}$.

Основним постулатом соиіально-психологічного підходу $\epsilon$ твердження про те, що імідж - це соціально-психологічний феномен $\mathrm{i}$ продукт соціального пізнання.

На думку Е.А. Володарської, існують соціально-психологічні детермінанти іміджу, які проявляються на рівнях особистості, групи i суспільства. Рівень особистості ця дослідниця пов'язує з детерминацією ціннісними орієнтаціями; на рівні групи відбувається детермінація типом аудиторії іміджу («специфіка групи за статтю, віком, сфері професійної діяльності, соціальна позиція особистості» ${ }^{23}$; на рівні суспільства імідж детермінується панівною ідеологією держави і особливостями масових комунікацій за допомогою засобів масової інформації.

У даному підході зміст іміджу також зв'язується зі змістом поняття «соціальна роль» і змістом поняття «соціальні уявлення». На думку Е.А. Дагаєвої ${ }^{24}$, «в рамках теорії соціальних уявлень імідж може інтерпретуватися як різновид соціального уявлення, який носить цілераціональний характер».

18 Дагаева Е.А. Методология изучения имиджа как социально-психологического феномена. Психологическая наука и образование. 2011. No 1. URL: www.psyedu.ru.

19 Почепцов Г.Г. Имиджелогия : теория и практика. Киев, 1998. 392 с. С. 11. C. 53.

20 Петрова Е.А. Визуальная психосемиотика общения. Москва, 2000. 452 с.

${ }^{21}$ Давыдов Д.Г. Социально-психологические особенности имиджа вооруженных сил России в молодежной среде : автореф. дис. ... канд. психол. Наук : 19.00.05. Москва, 2005. 23 с. С. 15.

22 Тульчинский Г.Л. Феноменология имиджа и метафизика идентичности. Символы, образы и стереотипы современной культуры : сб. статей. СанктПетербург : ЭЙДОС, 2000. С.100-112.

23 Володарская Е. А. Социально-психологическая концепция имиджа науки : автореф. дис. ... д-ра психол. наук : 19.00.05. Москва, 2009. 32 с. С. 24

24 Дагаева Е.А. Имидж как социально-коммуникативный феномен: теоретикометодологические аспекты изучения. Вестник Нижегородского университета университета им. Н.И. Лобачевского, 2011. № 4(1). С. 363-369, 364. 
Основний постулат соиіально-периептивного підходу - це твердження про те, що імідж формується як результат навмисного або ненавмисного створення першого враження. Наприклад, на думку М.В. Апраксиной, імідж - «безпосереднє або умисне створення візуально-аудиального враження про особу або соціальну структуру» ${ }^{25}$.

Феномен першого враження формується як результат діяльності соціально-перцептивних механізмів («ідентифікації», «атракції», «емпатії», «рефлексії», «казуальної атрибуції») і факторів («ефект ореолу», «ефект новизни і первинності», «стереотипізації») на початковій стадії формування іміджу ${ }^{26}$.

Процес сприйняття іншого опосередковується: за У. Найссером перцептивних схемами ${ }^{27}$, за Дж. Брунером - гіпотезами ${ }^{28}$, за Дж. Келлі - особистісними системами конструктів ${ }^{29}$, які направляють перцептивні і розумові дії в процесі сприйняття одержуваної інформації, завдяки чому створюється основа з імпліцитних переконань про сутність іншого.

Основним постулатом акмеологічного підходу є твердження про те, що імідж є продукт зрілості людини: рівень іміджу говорить про рівень зрілості людини, i, навпаки, рівень зрілості визначає рівень розвитку іміджу особистості.

Акмеологічний підхід $є$ орієнтованим на вивчення залежностей формування рівня іміджу від показників розвитку професіоналізму i компетентності, здатності особистості до самопізнання, саморозвитку, самовдосконалення, самореалізації.

Наприклад, Е.П. Костенко пропонує інтерпретувати суть поняття іміджу політика «не тільки як символічний образ, що відображає презентаційні риси політика ..., але і з позицій об'єктних і суб'єктних характеристик носія іміджу - політика, який відповідає за створюваний образ і прагне до розвитку і самовдосконалення 3 метою досягнення високих професійних результатів, найвищих показників ефективності в політичній діяльності» ${ }^{30}$.

${ }^{25}$ Апраксина М.В. Имидж воспитателя дошкольного учреждения как педагогическая проблема : дис. ... канд. пед. наук : 13.00 .02 / Ин-т повышения квалификации и переподготовки работников нар. образования. Москва, 2000. 134 с. С. 24.

26 Андреева Г.М. Социальная психология : учебник для высших учебных заведений. Москва : Аспект Пресс, 2001. 376 с.

27 Найссер У. Познание и реальность. Смысл и принципы когнитивной психологии. / пер. с англ. В.В Лучкова. Москва : Прогресс, 1981. 385 с.

28 Брунер Дж. Психология познания : за пределами непосредственной информации. / пер. с англ. К.И. Бабицкого. Москва : Прогресс, 1977. 345 с.

${ }^{2}$ Келли Дж. Теория личности. Психология личностных конструктов / пер. с англ. и науч. ред. А.А. Алексеева. Санкт-Петербург : Речь, 2000. 456 с.

30 Костенко Е.П. Акмеологическая концепция развития имиджа политика : автореф. дис. ...д-ра психол. наук : 23.00.02. Москва 2008. 34 с. С. 7. 
Основний постулат інтерсуб'ектівного підходу в вивченні іміджу, передбачає, що імідж - це образ інтерсуб'ектний, тобто виникає в результаті взаємодії між «суб'єктом-прообразом» іміджу і суб'єктами, що сприймають імідж.

Наприклад, Е.Б. Перелигіна визначає імідж як різновид образу, прообразом якого обов'язково є суб'єкт. На ï думку, імідж формується як «активна i цілеспрямована діяльність суб'єкта іміджу»" ${ }^{31}$ він формується «в процесі такого специфічного виду діяльності, як суб'єкт-суб' єктна взаємодія» ${ }^{32}$.

Основний постулат комунікативного підходу: імідж $\epsilon$ комунікативним феноменом, таким чином, його можна досліджувати виходячи 3 аналізу комунікаційних закономірностей: наявності комунікатора - комуніканта, повідомлення, каналів повідомлень та ін.

Подібна схема дає можливість досліджувати імідж, поетапно виділяючи зміст елементів комунікації, орієнтуючи дослідника i практика іміджу в рамках причинно-наслідкових зв'язків впливу іміджу.

У рамках цього підходу акцент робиться на інверсії уваги дослідників у напрямку до властивостей споживача іміджу: яким повинен бути імідж (та імідж-комунікації) для споживача іміджу, щоб забезпечувати успішність тривалого існування іміджу, зробити вплив на споживача іміджу, які властивості механізму комунікативного впливу повинні бути організовані.

Основний постулат суб'єктно-діяльнісного підходу: імідж розглядається як цілеспрямована активність ініціатора іміджу, яка необхідно призводить до певного результату, до змін в респонденті іміджу. Таким чином, акцент робиться на тому, за допомогою яких засобів, суб'єкт іміджу може вплинути на поведінку респондента іміджу, які дії він повинен зробити для зміни поведінки останнього.

На думку Е.Б. Перелигіної, імідж $є$ продуктом діяльності як спеціально організованої (проведеної фахівцями-іміджмейкерами на основі професійно вироблених стратегій і методів), так і стихійної (формується як результат назрілій необхідності задоволення актуалізованої потреби), але в будь-якому випадку імідж - це результат цілеспрямованої активності суб'єкта спілкування ${ }^{33}$.

31 Перелыгина Е.Б. Имидж как феномен интерсубъектного взаимодействия (Содержание и пути развития) : дис. ... д-ра психол. наук : 19.00.01. Москва, 2003. 35 с. C. 11.

32 Перелыгина Е.Б. Психология имиджа : учеб. пособие. Москва : Аспект Пресс, 2002. 223 c. C. 24

33 Перелыгина Е Б. Психология имиджа : учеб. пособие. Москва : Аспект Пресс, 2002. 223 c., C. 24. 
На думку Д.Г. Давидова, саме цілеспрямованість $є$ видовою особливістю іміджу: «Цілеспрямована діяльність суб'єкта, який здійснює створення або корекцію іміджу, мотивується розбіжністю уявлень про те, як повинен був би сприйматися об'єкт, і про те, як він реально сприймається. Метою такої діяльності є реалізація функцій іміджу» ${ }^{34}$.

У зв'язку із цим ряд дослідників ${ }^{35}$ прийшли до висновку про необхідність вивчення діяльності по формуванню іміджу (ДФІ).

Узагальнюючи зміст вище наведених підходів до дослідження іміджу особистості, ми висловимо думку (сформуємо синтетичне твердження), що імідж особистості являе собою знаково-символьну систему, щзо має візуальний, вербальний $і$ інші компоненти, яка створюється у процесі суб'єкт-об'єктного сприйняття $i$ суб'єктсуб'єктної взаємодії, яка може бути продуктом ијілеспрямованої діяльності, у прочесі якої відбувається створення «спеціально впізнаваного» образу особистості. Завдяки його формуванню у споживача іміджу складаються стійкі уявлення про характеристики носія іміджу і формується певне ставлення до даного суб 'єкта.

\section{2. Системний опис феномена іміджа особистості}

На нашу думку, все перераховане вище дає можливість сформувати системний опис іміджу особистості, загальним змістом якого будуть такі елементи, які відображені в підходах до вивчення іміджу:

- детермінація формування іміджу (соціально-психологічний аспект, акмеологічний аспект, діяльнісний аспект);

- носій іміджу;

- контекст взаємодії носія іміджу та одержувача іміджу;

- знаковий простір, сформований носієм іміджу;

- характер взаємодії (суб’єкт-суб'єктна взаємодія / суб'єктоб'єктна взаємодія);

- процес, форми, види, засоби комунікації;

- одержувач іміджу;

- детермінація отримання і прийняття іміджу (діяльнісний аспект, акмеологічний аспект, соціально-психологічний аспект).

Графічне співвідношення цих елементів представлено на Рис. 1.

34 Давыдов Д.Г. Социально-психологические особенности имиджа вооруженных сил России в молодежной среде : автореф. дис. ...канд. психол. наук : 19.00.05. Москва, 2005. 23 с. С. 10

35 Перелыгина Е.Б. Психология имиджа : учеб. пособие. Москва : Аспект Пресс, 2002. 223 с. та ін. 


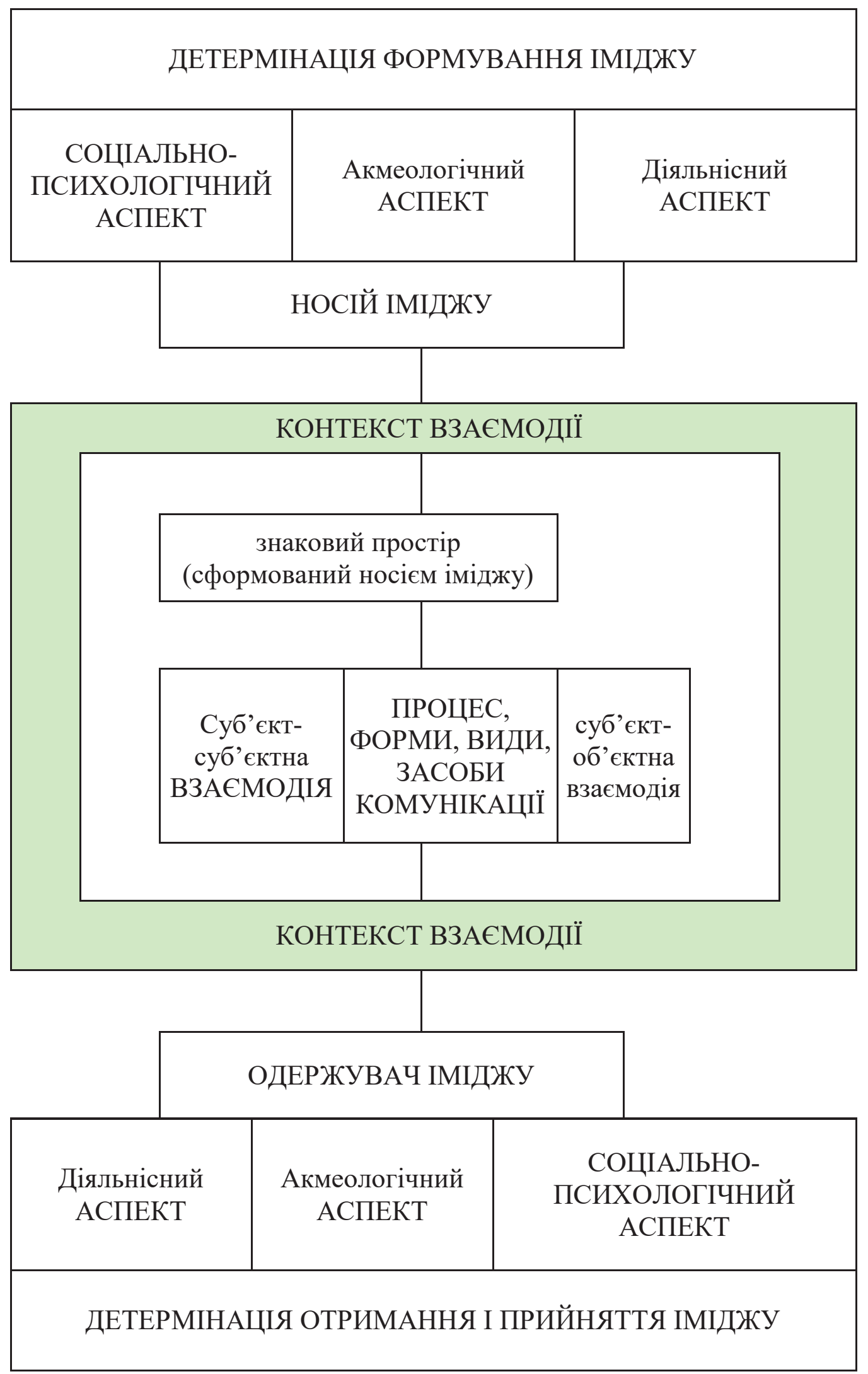

Рис. 1. Графічне співвідношення елементів системного опису іміджу особистості 
Зміст елементів, які формують системний опис іміджу, ми формулюємо наступним чином.

Детермінація формування іміджу особистості - сукупність факторів різної природи, які утворюють вплив на процес і результат формування i функціонування іміджу как прояву особистості.

Із нашої точки зору, виходячи з аналізу вищенаведеної літератури, в першу чергу можливе видиліти: соціально-психологічний аспект детермінації іміджу особистості, акмеологічний аспект детермінації іміджу особистості, діяльнісний аспект детермінації іміджу особистості.

Соціально-психологічний аспект детермінації іміджу особистості, 3 нашої точки зору, є наслідок процесу та результату взаємодії носія іміджу з іншими людьми, соціальними групами, суспільством у цілому. Вплив провідної політичної ідеології держави, громадської думки, 3МІ, обміну думок з представниками референтних груп, сімейних стосунків та інших форм публічної та міжособистісної взаємодії формує ціннісні орієнтації особистості відносно того, якими якісними характеристиками повинен володіти інший, який займається тією чи іншою справою, належить до тієї чи іншої соціальної організації або групи. Характер цього впливу залежить від особливостей включенності особистості в суспільні зв'язки 3 іншими та міри тї активності. Різноманітність соціальних зв'язків і інтересів особистості формують більш розвинуте уявлення щодо якості суспільних стосунків, таким чином формучі більш витончені потреби відносно якості презентації себе у суспільстві.

Крім того, деякі організаційні структури та соціальні групи нав'язують необхідне дотримання певних ритуалів i / або носіння знаків уніформи (або застосування інших способи знакового виділення себе $з$ середовища). Задоволення потреби приналежності до таких груп або організацій формує потребу дотримання канонів та очікування того, що інші будуть вести себе схоже.

Акмеологічний аспект детермінаиії іміджу особистості, на нашу думку, пов'язаний із досягнутим особистістю на даний момент рівнем зрілості, що дозволяє формувати імідж і особистісне вплив на інших за допомогою іміджу. Імідж, таким чином, формується як результат ступеня усвідомлення особистістю вимог до іï рівня самореалізації відповідно до вимог тієї діяльності, в яку включена дана особистість.

У самому широкому розумінні «особистісна зрілість» визначається як вищий рівень розвитку людини, пов'язаний 3 формуванням i стабілізацією у неї певних якостей.

Наприклад, О. Штепа вважає особистісну зрілість ключовим новоутворенням віку «у вигляді онтологічного ядра особистості, 
важливого для его-ідентичності. Вона $є$ одночасно критерієм особистісного зростання та виявом особистісного потенціалу людини» ${ }^{36}$.

Таким чином, вплив акмеологічного аспекту детермінації формування іміджу можливе простежити як процес i результат усвідомлення особістістю необхідності відповідати своєму досягнутому рівню розвитку, який пов'язаний з уявленнями про вимоги середовища до даного рівня розвитку. Усвідомлення змін свого рівня розвитку, на наш погляд, стає мотиватором для включення особистості в діяльність по формуванню іміджу.

Діяльнісний аспект детермінації іміджу особистості, на нашу думку, пов'язаний 3 особливостями діяльності, в яку включена особистість.

Виконання складних публічних видів діяльності, які пов'язані 3 необхідністю підпорядкування певним соціокультурним та корпоративним нормам поведінки (діяльність державного службовця, військовослужбовця, поліцейського, лікаря, педагога і ін.), вимагає від особистості необхідності врахування цих норм і залежно від жорсткості вимог до виконання соціальної ролі і рівня статусу - дотримання їх.

Особливістю діяльнісного аспекту детермінації іміджу особистості, на наш погляд, $\epsilon$, в першу чергу, орієнтація особистості в ході виконання діяльності на корпоративні вимоги (вимоги групи, яка об’єднана спільною діяльністю), що дозволяє говорити про схожість даної детермінації 3 детерминацией соціально-психологічної. Відмінність діяльнісного аспекту детермінації іміджу від детермінації соціально-психологічної в даному випадку простежується у вказівці на те, що соціально-психологічна детермінація - це, в першу чергу, вплив на імідж особистості 3 боку лідерів думок, які були в досвіді особистості раніше (на більш ранніх етапах ii розвитку), але не включені в поточну діяльність зараз.

Носій іміджу - особистість, що займається публічною діяльністю, включена у взаємодію з соціальним середовищем в якості суб'єкта в зв’язку з необхідністю виконання своєї соціальної ролі.

Основними характеристиками носія іміджу, що впливають на процес формування, розвитку і пред'явлення іміджу, 3 нашої точки зору, є: сформований в особистості комплекс вікових, біологічних, психологічних і соціальних властивостей, досвід, функціональний стан, відношення до одержувача іміджу.

36 Штепа О. Феномен особистісної зрілості. Соціальна психологія. 2005. № 1. C. 62-77. 
Цей комплекс властивостей знаходить своє відображення в характеристиках знакового простору, організованого носієм іміджу, а саме в тих системах, за допомогою яких можливо організувати вплив на получетеля іміджу. Це: система вербальних проявів, система невербальних проявів, система «габітусу», система «костюма», система «запаху», система «оточення».

Одержувач іміджу - особистість, яка включена в публічну діяльність, як суб'єкт і об'єкт взаємодії, і, в силу цієї включеності, попадає під вплив носія іміджу, що призводить до певних внутрішніх і / або зовнішніх змін у неї.

Основними характеристиками одержувача іміджу, що впливають на процес і результат отримання іміджу, з нашої точки зору є: вікові, біологічні, психологічні, соціальні властивості одержувача іміджу, досвід, функціональний стан, сформоване ставлення до носія іміджу і до ситуації взаємодії з ним.

Взаємодія між носієм іміджу $і$ одержувачем іміджу включена в певний контекст і носить суб'єкт-суб'єктний або суб'єкт-об'єктний характер, забарвлюється характером комунікації.

Контекст взаємодії носія і одержувача іміджу, з нашої точки зору, може бути описаний в широкому і вузькому планах. Широкий план опису контексту взаємодії включає в себе всю сукупність соціальних і соціально-психологічних явищ, супутніх взаємодії між учасниками (наприклад, політика держави в тій чи іншій сфері, характер заходів, схожість і відмінність ідеологічних поглядів, присутність інших, конкурентні відносини та ін.). Вузький план опису контексту взаємодії конкретизує в собі обмежене конкретною формою комунікації коло явищ (наприклад, особиста зустріч за відсутності інших учасників характеризується одним обмеженим контекстом, в той час як вплив перегляду каналу телемовлення іншим).

Суб'єкт-суб'єктна взаємодія носія іміджу та одержувача іміджу характеризується взаємної спрямованістю учасників один на одного як на значущих осіб, характеризується проникненням у внутрішній світ іншого і переживанням досвіду спільної взаємодії. У процесі суб'єктсуб'єктної взаємодії створюється взаємопроникнення розумової i чуттєвої сфер учасників взаємодії, завдяки чому з'являється можливість глибокого розуміння один одного і співпраці.

Суб 'єкт-об'єктна взаємодія носія іміджу та одержувача іміджу має відмінні від суб'єкт-суб'єктної взаємодії характеристики. В даному випадку носій іміджу виступає в якості суб'єкта взаємодії, є активною сторону взаємодії, а одержувач іміджу виступає у вигляді пасивної сторони (постає як об'єкт впливу), його можливості в плані проникнення у внутрішній світ носія іміджу обмежені цілями i 
процедурою взаємодії. Формується односпрямованість комунікації: від носія іміджу до іiі одержувачу, в результаті чого ступінь свободи поведінки одержувача іміджу може істотно обмежуватися.

Взаємодія між носієм іміджу і одержувачем іміджу можливо описати і як комунікаційний процес з усіма його складовими: ініціатор повідомлення (носій іміджу), імідж-повідомлення, вид повідомлення (вербальне імідж-повідомлення / невербальне імідж-повідомлення, які підкреслюють особливості носія іміджу), канал повідомлення (природний при особистих зустрічах, штучний при використанні технічних засобів), шуми, перешкоди, одержувач повідомлення (одержувач іміджу), зворотний зв'язок.

Надіслане імідж-повідомлення (імідж носія), 3 нашої точки зору, має можливість бути отриманим (або не отриманим) одержувачем іміджу і прийнятим (або не прийнятим) отримувачем іміджу.

Результативність отримання / неотримання, прийняття / неприйняття іміджу обумовлена, з нашої точки зору, функціонуванням у одержувача іміджу певної детермінації отримання і прийняття іміджу.

Детермінаиія отримання $і$ прийняття іміджу, на нашу думку, це сукупність факторів, які зумовлюють спрямованість одержувача іміджу на сприйняття іміджу носія (1), формування позитивного ставлення до носія іміджу (2) і включеність у взаємодію 3 носієм іміджу (3). Це $є$ явища, які впливають на інтенсивність включеності одержувача іміджу в ситуацію взаємодії з носієм, на характер интеракций між ними, на результат комунікації.

Отримання i прийняття іміджу опосередковано досвідом, функціональним станом одержувача іміджу, ставленням до носія іміджу і до ситуації взаємодії 3 ним. Отриманий імідж - це повідомлення, яке формує привернення уваги одержувача іміджу щодо носія іміджу. Відмова від отримання іміджу пов'язана, на нашу думку, 3 перекладом уваги на інші елементи ситуації взаємодії (в тому числі 3 формуванням розумових операцій і дій, не пов'язаних 3 ситуацією взаємодії і імідж-носієм).

Прийнятий імідж характеризується формуванням позитивного ставлення до носія іміджу та спрямованістю на взаємодію з ним. Відмова від прийняття іміджу характеризується формуванням негативних емоційних станів по відношенню до носія іміджу, закономірно впливає на формування бар'єрів комунікації.

У детермінації отримання і прийняття іміджу нами виділяється три основних аспекти: діяльнісний аспект, акмеологічний аспект, соціально-психологічний аспект.

Діяльнісний аспект отримання і прийняття іміджу, з нашої точки зору, пов'язаний із виділенням в якості гіпотетичного особливого виду 
внутрішньої діяльності - діяльності з отримання та прийняття іміджу, яка характеризується певним функціонуванням комплексу мотиваційних, пізнавальних, емоційних процесів. Серед складових частин цього комплексу: мотиваційні похідні (потреби, інтереси, схильності, установки, домагання особистості), когнітивні стани, операції, дії (спрямованість, зосередженість уваги на носії іміджу, добудовування цілісного образу на основі сприйнятих знаків, формування константності образу, вилучення 3 пам'яті інформації, порівняння сприйманого 3 уже наявним досвідом, умовивід про значимість сприйнятого та ін.), емоційні реакції (радість, страх, ненависть, злість, відраза та ін.). Результатом цієї діяльності $\epsilon$ прийняття / неприйняття іміджу, прагнення до подальшої взаємодії 3 носієм іміджу або відмова від взаємодії з ним.

Акмеологічний аспект детермінації отримання і прийняття іміджу пов'язаний з характеристиками рівня розвитку одержувача іміджу. На нашу думку, уявлення про себе як про суб'єкта розвитку, який характеризується тим чи іншим рівнем самовідношення i самоактуалізації, формує певне ставлення до одержуваної інформації, пов'язане з розвитком фільтрів, що визначають характер прийняття або неприйняття інформації. Високий рівень розуміння своїх особливостей як суб'єкта розвитку зв'язується з розвиненим представленням про характер своїх потреб i прийнятних способах їх задоволення. Прийняття / неприйняття іміджу, таким чином, ставиться в залежність від результату усвідомлення потрібності імідженосітеля для одержувача як такого або як засобу, способу задоволення своїх потреб.

Соиіально-психологічний аспект детермінації отримання і прийняття іміджу представлет собою сукупність факторів, які формуються як результат узагальнення впливів з боку суспільства, соціальних груп, референтних носіїв інформації. Обмін досвідом з іншими і про інших в ході спілкування формує соціальні уявлення та соціальні стереотипи, участь у виконанні тих чи інших ролей створює навички розпізнавання характеристик рольового виконання. Вплив ЗМІ формує певне ставлення до знакових і статусних суспільних фігур. Під впливом цих та інших зовнішніх впливів формується неусвідомлюване уявлення про «ідеального» носія іміджу - представника того чи іншого досвіду, тієї чи іншої соціальної групи, організації, яке функціонує як порівняльний образ во взаїмодії з образом сприйняття, що впливає на процес i результат детермінації отримання і прийняття іміджу.

\section{ВИСНОВКИ}

Метою нашого дослідження було: на основі аналізу наукової літератури, присвяченій тематиці вивчення іміджу, запропонувати до розгляду модель системного опису іміджу особистості. 
Аналіз літератури дозволив сформулювати основні положення моделі системного опису іміджу особистості, яка включає такі компоненти: детермінація формування іміджу (соиіальнопсихологічний аспект, акмеологічний аспект, діяльнісний аспект); носій іміджу; контекст взаємодії носія іміджу та одержувача іміджу; знаковий простір, сформований носієм іміджу; характер взаємодї (суб'єкт-суб'єктна взаємодія / суб 'єкт-об'єктна взаємодія); проиес, форми, види, засоби комунікаиії; одержувач іміджу; детерміначія отримання i прийняття іміджу (діяльнісний аспект, акмеологічний аспект, соціально-психологічний аспект).

Ми вважаємо, що системний опис іміджу особистості, сформульоване нами дозволяє конкретизувати напрямки дослідження іміджу особистості. У найближчому наближенні це такі напрямки:

- дослідження детермінації формування іміджу особистості (особливості проявів соціально-психологічної, акмеологічної, діяльнісної детермінації формування іміджу особистості);

- дослідження характеру впливу особливостей носія іміджу (вікових, біологічних, психологічних, соціальних властивостей носія іміджу, досвіду, функціонального стану, сформованого ставлення до одержувача іміджу і до ситуації взаємодії з ним) на процес і результат формування іміджу;

- дослідження процесу і результату впливів контексту взаємодії носія іміджу та одержувача іміджу на формування іміджу;

- дослідження характеристик знакових просторів, які формує носій іміджу;

- дослідження впливу суб'єкт-суб'єктної та суб'єкт-об'єктної взаємодії на процес і результати формування іміджу;

- дослідження впливу комунікативних процесів на формування i функціонування іміджу;

- дослідження впливу особливостей одержувача іміджу на формування іміджу;

- дослідження детермінації отримання і прийняття іміджу (впливу діяльнісної детермінації, акмеологической детермінації, соціальнопсихологічної детермінації на результат функціонування іміджу).

Подальший розвиток досліджень у цій області дозволять уточнити модель системного опису іміджу особистості.

\section{АНОТАЦІЯ}

У нашому дослідженні ми проаналізували сучасний науковий досвід, присвячений вивченню іміджу особистості.

Підкреслили, що імідж $є$ однією зі сторін масової свідомості свідомості буденної, яка характеризується своїми особливостями, і через ці особливості впливає на формування поведінки людей. 
Виділили основні взгляди на природу іміджу. 3 точки зору більшості авторів, що спеціалізуються в даній проблематиці, імідж характеризується численністю факторів, що впливають на його формування та функціонування. Разом із цим авторами найчастіше підкреслюється соціальний генезис і соціальна спрямованість іміджу особистості. Характерною рисою даного етапу розвитку психології іміджу є відсутність загальної теорії іміджу. Різноманітність наявних в літературі визначень стає характерним прикладом різноманітності наукових поглядів на природу іміджу особистості.

Таким чином, аналіз сучасних наукових поглядів на імідж особистості диктує необхідність формування системного підходу до вивчення іміджу особистості. Основним змістом системного підходу до вивчення іміджу особистості повинні стати, на нашу думку, такі основні елементи: носій і одержувач іміджу, контекст взаємодії між ними, детермінація створення іміджу, детермінація отримання i прийняття іміджу.

На підставі аналізу літератури нами були виділені основні підходи до вивчення іміджу особистості (1), сформульовано синтетичне визначення іміджу особистості (2), сформовані основні положення авторської моделі системного опису іміджу особистості (3), запропоновані основні напрямки дослідженнь іміджу особистості (4).

\section{ЛІТЕРАТУРА}

1. Андреева Г.М. Социальная психология : учебник для высших учебных заведений. Москва : Аспект Пресс, 2001. 376 с.

2. Апраксина М.В. Имидж воспитателя дошкольного учреждения как педагогическая проблема : дис. ... канд. пед. наук : 13.00 .02 / Ин-т повышения квалификации и переподготовки работников нар. образования. Москва, 2000. 134 с.

3. Брунер Дж. Психология познания : за пределами непосредственной информации. / пер. с англ. К.И. Бабицкого. Москва : Прогресс, 1977. 345 с.

4. Бурстин Д. Імидж. Санкт-Петербург : Питер, 2000. 216 с.

5. Володарская Е.Я. Социально-психологическая концепция имиджа науки : автореф. дис. ... д-ра психол. наук : 19.00.05. Москва, 2009. 32 c.

6. Гуревич П. Приключение имиджа. Москва, 1995, 226 с.

7. Давыдов Д.Г. Социально-психологические особенности имиджа вооруженных сил России в молодежной среде : автореф. дис. ... канд. психол. наук : 19.00.05. Москва, 2005. 23 с.

8. Дагаева Е.А. Имидж как социально-коммуникативный феномен: теоретико-методологические аспекты изучения. Вестник 
Нижегородского университета университета им. Н.И. Лобачевского, 2011. № 4(1). C. 363-369.

9. Дагаева Е.А. Методология изучения имиджа как социальнопсихологического феномена. Психологическая наука и образование. 2011. № 1. URL: www.psyedu.ru.

10. Дубинин И.И. Динамика обыденного сознания. Минск : изд-во «Университетское», 1985. 224 с.

11. Егорова-Гантман Е. Политическая реклама. Москва, 1999. 327 с.

12. Зверинцев А.Б. Коммуникационный менеджмент. СанктПетербург, 1997. 286 с.

13. Келли Дж. Теория личности. Психология личностных конструктов / пер. с англ. и науч. ред. А.А. Алексеева. Санкт-Петербург : Речь, 2000. 456 с.

14. Костенко Е.П. Акмеологическая концепция развития имиджа политика : автореф. дис. ...д-ра психол. наук : 23.00.02. Москва, 2008. $34 \mathrm{c}$.

15. Найссер У. Познание и реальность. Смысл и принципы когнитивной психологии. / пер. с англ. В.В Лучкова. Москва : Прогресс, 1981.385 с.

16. Нефедова И. Я и мой имидж. Москва : Яуза : ЭКСМО-Пресс, 1997. 208 c.

17. Орлова Е.А. Формирование позитивного имиджа государственного деятеля (Социально-психологический аспект) : дис. ... канд. психол. наук : 19.00.05. Москва, 1997. 217 с.

18. Панасюк А.Ю. Вам нужен имиджмейкер? Или о том, как создать свой имидж. Москва, 1998. 346 с.

19. Перелыгина Е.Б. Имидж как феномен интерсубъектного взаимодействия (Содержание и пути развития) : дис. ... д-ра психол. наук : 19.00.01. Москва, 2003. 35 с.

20. Перелыгина Е.Б. Психология имиджа : учеб. пособие. Москва : Аспект Пресс, 2002. 223 с.

21. Петрова Е.А. Визуальная психосемиотика общения. Москва, 2000. 452 c.

22. Петрова Е.А. Имиджелогия : современное и состояние и перспективы развития. Москва : Альфа, 2003. 326 с.

23. Почепцов Г.Г. Имиджелогия : теория и практика. Киев, 1998. $392 \mathrm{c}$.

24. Пызин В.А. Профессиональный выбор и отбор персонала. Москва, 1997. 244 с.

25. Тульчинский Г.Л. Феноменология имиджа и метафизика идентичности. Символь, образы и стереотипь современной культуры : сб. статей. Санкт-Петербург : ЭЙДОС, 2000. 
26. Феофанов О.А. Агрессия лжи. Москва, 1987. 228 с.

27. Шепель В.М. Имиджелогия. Секреты личного обаяния. Москва, 1994. $384 \mathrm{c}$.

28. Шепель В.М. Имиджелогия. Как нравиться людям. Москва : Народное образование, 2002. 576 с.

29. Штепа О. Феномен особистісної зрілості. Соціальна психологія. 2005. № 1 .

Information about the author:

Demchuk T. P., Ph.D. (Psychology), Senior Lecturer at the Psychology and Pedagogy Department Dnipropetrovsk State University of Internal Affairs 26, Gagarin Avenue, Dnipro, Ukraine 